\title{
Pathogenic DNM1 Gene Variant Presenting With Unusually Nonsevere Neurodevelopmental Phenotype: A Case Report
}

Elaine Choi, MD, MSc, Breanne Dale, MSc, Rajesh RamachandranNair, MD, FRCPCH, FRCPC, and Resham Ejaz, MD, FRCPC, FCCMG

Neurol Genet 2021;7:e618. doi:10.1212/NXG.0000000000000618

\author{
Correspondence \\ Dr. Ejaz \\ ejazr@mcmaster.ca
}

\section{Abstract}

\section{Background and Objectives}

To date, all reports of pathogenic variants affecting the GTPase domain of the DNM1 gene have a clinically severe neurodevelopmental phenotype, including severe delays or intractable epilepsy. We describe a case with moderate developmental delays and self-resolved epilepsy.

\section{Methods}

The patient was followed by our neurology and genetics teams. After clinical examination and EEG to characterize the patient's presentation, we conducted etiologic workup including brain MRI, chromosomal microarray, genetic and metabolic investigations, and nerve conduction studies. Subsequently, we arranged an Intellectual Disability Plus Trio Panel.

\section{Results}

Our patient presented with seizures at 2 days old, requiring phenobarbital. She also had hypotonia, mild dysmorphic features, and mild ataxia. Although initial workup returned unremarkable, the trio gene panel identified a de novo heterozygous pathogenic missense variant in the DNM1 GTPase domain. Now 4 years old, she has been seizure-free for 3 years without ongoing treatment and has nonsevere developmental delays (e.g., ambulates independently and speaks 2-word phrases).

\section{Discussion}

Our case confirms that not all individuals with DNM1 pathogenic variants, even affecting the GTPase domain, will present with intractable epilepsy or severe delays. Expanding the known clinical spectrum of dynamin-related neurodevelopmental disorder is crucial for patient prognostication and counseling. 
Up to $2 \%$ of patients with developmental epileptic encephalopathies (infantile-onset refractory epilepsies with neurodevelopmental delays) have pathogenic variants in the DNM1 gene (MIM: 616346). ${ }^{1}$ DNM1 encodes dynamin, a brain-expressed GTPase essential for neurotransmitter vesicle recycling after fusion with the presynaptic neuronal membrane. ${ }^{2}$ DNM1 has 5 domains: a GTPase domain to fuel vesicle scission, GTPase effector and middle domains for oligomerization, and pleckstrin homology and proline-rich domains for protein interactions. ${ }^{2}$ Most reported pathogenic DNM1 variants have dominant-negative effects on the
GTPase domain, ${ }^{1,3}$ where dysfunctional vesicle recycling results in synaptic dysfunction, leading to seizures and developmental delays. ${ }^{4}$ All reported patients with pathogenic variants affecting the GTPase domain have severe neurodevelopmental phenotypes, with severe-to-profound intellectual disability, global developmental delay (GDD), and treatment-refractory seizures. ${ }^{4,5}$ In 2 cases with milder phenotypes, the variants did not involve the GTPase domain. ${ }^{6}$ We present an individual with a DNM1 pathogenic variant affecting dynamin's GTPase domain, with a nonsevere phenotype.

Figure 1 EEG Findings
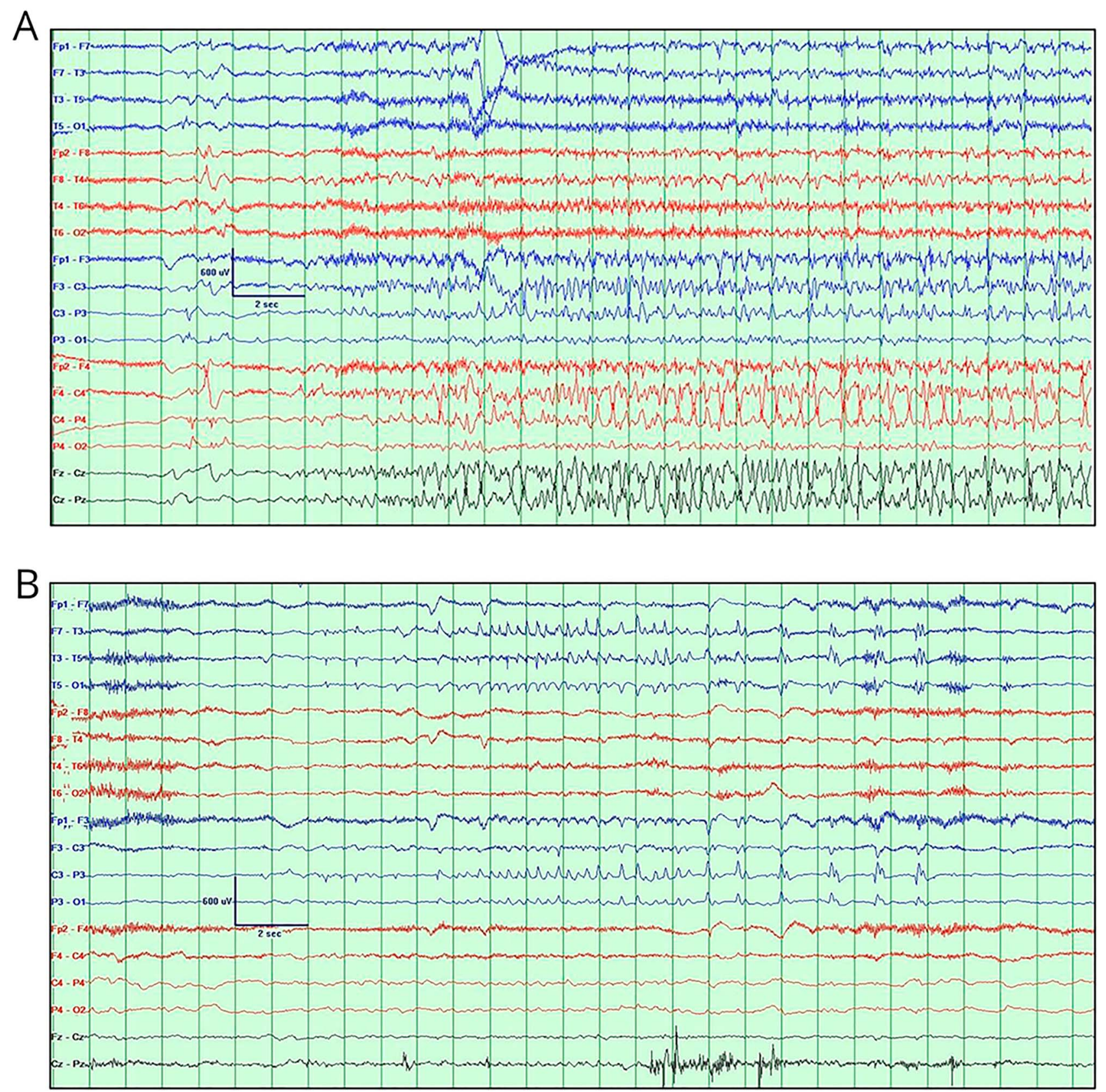

Awake EEG in anterior-posterior bipolar montage, showing (A) generalized seizure and (B) a 17-second seizure from the left temporal region. 
Figure 2 Genetic Testing Findings

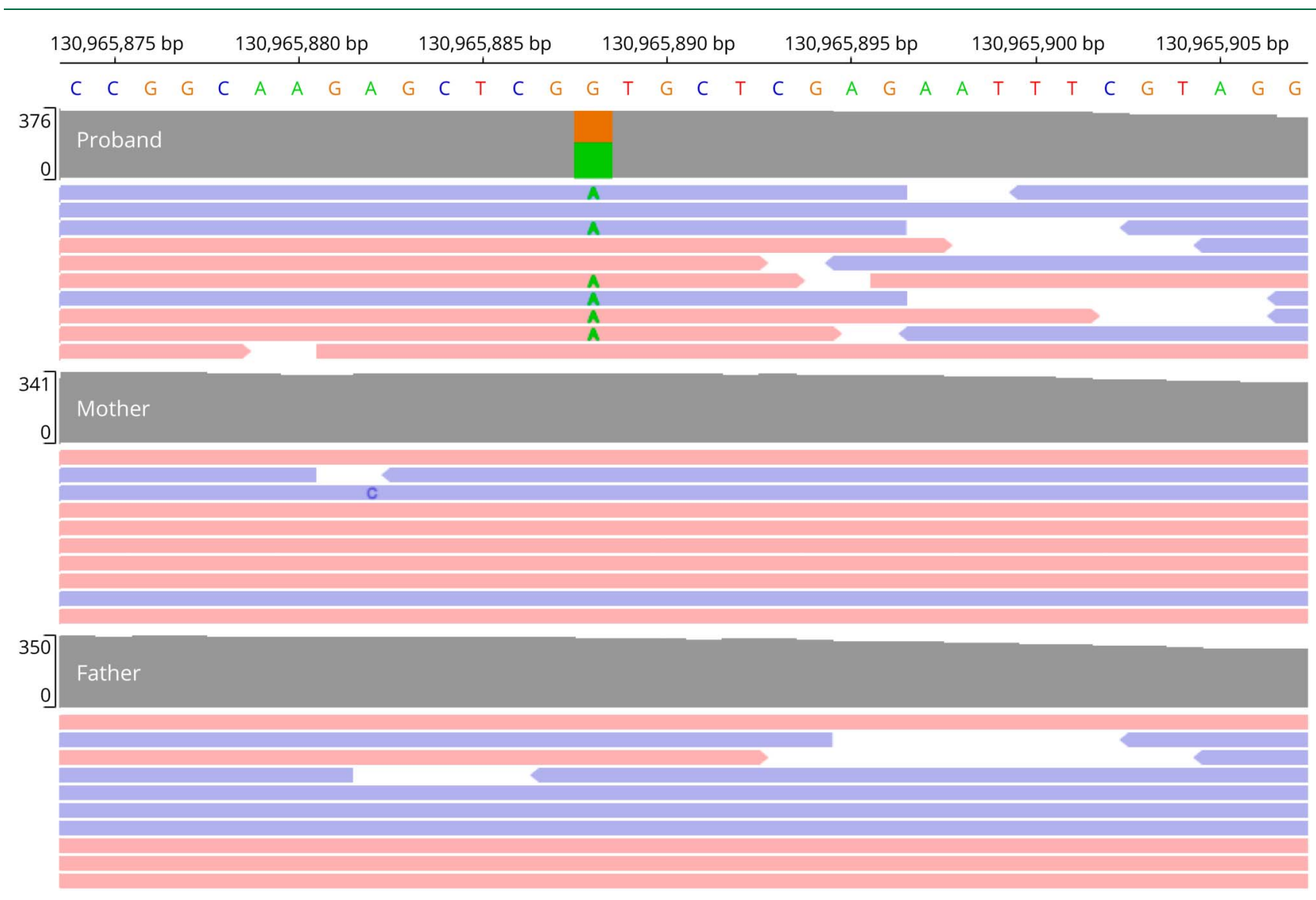

Read depth encompassing the missense variant (red/green squares, chr9 g.130965888G $>A$ ) in the next-generation sequencing from the patient (top) as compared with that from her parents (bottom two). Vertical gray lines indicate read depth. Horizontal blue and red lines indicate sequence reads aligned to hg19 reference genome. Original image obtained from Fulgent, edited by authors.

\section{Methods}

The individual was assessed by our neurology and genetics teams over 9 visits. We conducted prolonged EEG, brain MRI, chromosomal microarray, metabolic workup (plasma amino acids, acylcarnitines, urine organic acids, very long chain fatty acids, creatine kinase, urine creatine metabolites, and urine purines/pyrimidines), testing for Angelman and Rett syndromes, nerve conduction studies, and Intellectual Disability Plus Trio Panel (Fulgent, Temple City, CA). Parental consent to disclose was received.

\section{Results}

Our patient is a 4-year-old girl, born at term to consanguineous, healthy parents after an unremarkable pregnancy. At 2 days old, she developed weekly focal motor seizures lasting 30 seconds. By 1.5 months old, the episodes progressed to twice daily with bilateral tonic-clonic convulsions. An initial examination revealed hypotonia. Family history included 11 healthy siblings.

Prolonged EEG captured 2 seizures (Figure 1) and interictal epileptiform discharges from the left temporal region. The brain MRI was normal at 2 months old. She was started on phenobarbital. After a 1-year seizure-free period, she was weaned off phenobarbital, soon after which she experienced 2 further seizures; family declined restarting medication. Currently, she has been seizure-free for 3 years while off medication, so repeat EEG has not been conducted.

She sat unsupported, crawled, and walked at age 18 months, 2 years, and 3 years, respectively. She still used a palmar grasp at age 2 years but scribbled at 4 years. She had 2 words at age 2 years and 25 words at age 4 years, including 2 -word phrases. Developmental pediatric assessment at age 3.5 years confirmed GDD, with a 12-15-month functioning. At age 4 years, she understands 2 -step commands, makes eye contact, reciprocates facial expressions, waves goodbye, and plays with siblings. She uses utensils, recognizes animals, and washes hands unassisted. She is not toilet-trained and cannot copy shapes or dress herself. There have been no regressions.

At age 4 years, head circumference was $50.1 \mathrm{~cm}$ (73rd percentile), height $95.8 \mathrm{~cm}$ (9th percentile), and weight $14.1 \mathrm{~kg}$ (21st percentile). She had deep-set eyes, broad nose, tall 
forehead, open mouth, borderline low-set ears, single palmar creases, and mildly wide-based gait.

Nerve conduction studies, repeat brain MRI at age 2 years, metabolic workup, and testing for Angelman and Rett syndromes were unremarkable. Chromosomal microarray revealed a $226-\mathrm{kb}$ deletion on chromosome 6q12, likely benign. Multiple stretches of homozygosity were identified, consistent with consanguinity.

Intellectual Disability Plus Trio Panel revealed a de novo heterozygous pathogenic missense variant in DNM1 (c.139G $>\mathrm{A}$, p.Val47Met) (Figure 2).

\section{Discussion}

Our case illustrates that DNM1 pathogenic variants do not consistently result in intractable epilepsy or severe delays. Similar to previous descriptions of DNM1 variants, ${ }^{1}$ our patient's presentation included seizures, hypotonia, and ataxia. However, unlike reported cases, ${ }^{3}$ her seizures resolved without ongoing treatment, and her developmental delay is neither profound nor progressive.

Her specific variant results in a conservative amino acid change in DNM1's GTPase domain. This variant has been reported in 2 other individuals, both more clinically severe. One has ongoing seizures, moderate intellectual disability, speech delay, macrocephaly, and hypotonia. ${ }^{7}$ The other has epileptic encephalopathy, GDD, cerebellar ataxia, hypotonia, and stereotypy (ClinVar). Our patient may have milder phenotype because of various factors, including biological (e.g., potential gene interactions resulting in differential dynamin expression) and environmental (e.g., early interventions maximizing developmental potential) factors. Detailed molecular and functional analyses were not possible for this clinical report.

In summary, we report a case of nonsevere developmental delays and self-limited seizures associated with a pathogenic variant affecting the GTPase domain of DNM1. This study expands the clinical spectrum of dynamin-related neurodevelopmental disorders, suggesting that milder phenotypes may be underreported. Understanding the variable phenotype associated with DNM1, even within the same genotype, is instrumental for accurate prognostication and counseling because not all individuals have severe delays or intractable seizures.

\section{Acknowledgment}

The authors thank the patient and her parents, who provided consent for case report publication.

\section{Study Funding}

No targeted funding reported.

\section{Disclosure}

E. Choi, B. Dale, R. RamachandranNair, and R. Ejaz report no disclosures relevant to the manuscript. Go to Neurology.org/ NG for full disclosures.

\section{Publication History}

Received by Neurology: Genetics March 24, 2021. Accepted in final form June 28, 2021.

\begin{tabular}{lll}
\multicolumn{2}{l}{ Appendix Authors } & \\
\hline Name & Location & Contribution \\
\hline Elaine Choi, MD, MSc & $\begin{array}{l}\text { McMaster } \\
\text { University, } \\
\text { Hamilton, Ontario, } \\
\text { Canada }\end{array}$ & $\begin{array}{l}\text { Drafted the article for } \\
\text { intellectual content }\end{array}$ \\
\hline Breanne Dale, MSc & $\begin{array}{l}\text { McMaster } \\
\text { University, } \\
\text { Hamilton, Ontario, } \\
\text { Canada }\end{array}$ & $\begin{array}{l}\text { Interpreted the data and } \\
\text { revised the article for } \\
\text { intellectual content }\end{array}$ \\
\hline $\begin{array}{l}\text { Rajesh } \\
\text { RamachandranNair, } \\
\text { MD, FRCPCH, FRCPC }\end{array}$ & $\begin{array}{l}\text { University, } \\
\text { Hamilton, Ontario, } \\
\text { Canada }\end{array}$ & $\begin{array}{l}\text { Interpreted the data and } \\
\text { revised the article for } \\
\text { intellectual content }\end{array}$ \\
\hline $\begin{array}{l}\text { Resham Ejaz, MD, } \\
\text { FRCPC, FCCMG }\end{array}$ & $\begin{array}{l}\text { McMaster } \\
\text { University, } \\
\text { Hamilton, Ontario, } \\
\text { Canada }\end{array}$ & $\begin{array}{l}\text { Interpreted the data and } \\
\text { revised the article for } \\
\text { intellectual content }\end{array}$ \\
\hline
\end{tabular}

\section{References}

1. EuroEPINOMICS-RES Consortium, Epilepsy Phenome/Genome Project, Epi4K Consortium. De novo mutations in synaptic transmission genes including DNM1 cause epileptic encephalopathies. Am J Hum Genet. 2014;95(4):360-370.

2. Boumil $\mathrm{R}$, Letts $\mathrm{V}$, Roberts $\mathrm{M}$, et al. A missense mutation in a highly conserved alternate exon of dynamin-1 causes epilepsy in fitful mice. PLoS Genet. 2010;6(8):e1001046.

3. Von Spiczak S, Helbig K, Shinde D, et al. DNM1 encephalopathy: a new disease of vesicle fission. Neurology. 2017;89(4):385-394.

4. Li H, Fang F, Xu M, et al. Clinical assessments and EEG analyses of encephalopathies associated with dynamin-1 mutation. Front Pharmacol. 2019;10:1454.

5. The Deciphering Developmental Disorders Study. Large-scale discovery of novel genetic causes of developmental disorders. Nature. 2015;519(7542):223-228.

6. Brereton E, Fassi E, Araujo GC, et al. Mutations in the PH Domain of DNM1 are associated with a nonepileptic phenotype characterized by developmental delay and neurobehavioral abnormalities. Mol Genet Genomic Med. 2018;6(2):294-300.

7. Bowling K, Thompson M, Amaral M, et al. Genomic diagnosis for children with intellectual disability and/or developmental delay. Genome Med. 2017;9(1):43. 


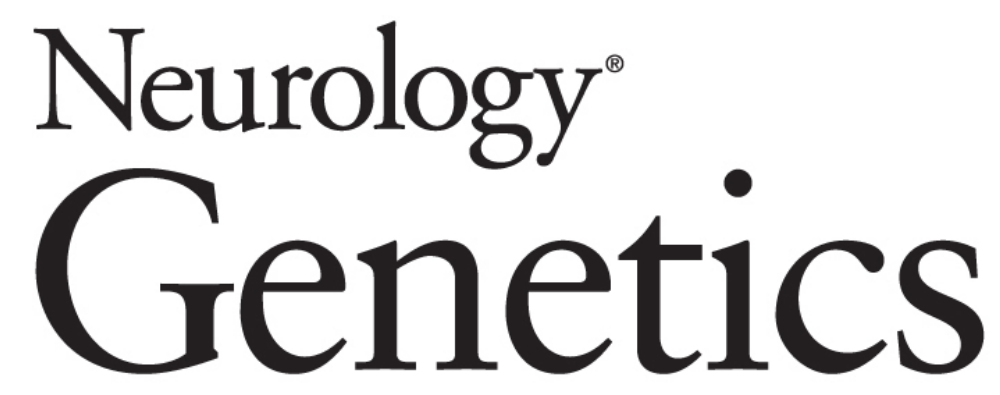

\section{Pathogenic DNM1 Gene Variant Presenting With Unusually Nonsevere Neurodevelopmental Phenotype: A Case Report \\ Elaine Choi, Breanne Dale, Rajesh RamachandranNair, et al. \\ Neurol Genet 2021;7; \\ DOI 10.1212/NXG.0000000000000618}

This information is current as of August 10, 2021

\section{Updated Information \& Services}

References

Citations

Subspecialty Collections

Permissions \& Licensing

Reprints including high resolution figures, can be found at: http://ng.neurology.org/content/7/5/e618.full.html

This article cites 7 articles, 0 of which you can access for free at: http://ng.neurology.org/content/7/5/e618.full.html\#\#ref-list-1

This article has been cited by 1 HighWire-hosted articles: http://ng.neurology.org/content/7/5/e618.full.html\#\#otherarticles

This article, along with others on similar topics, appears in the following collection(s):

All Epilepsy/Seizures

http://ng.neurology.org//cgi/collection/all_epilepsy_seizures

Developmental disorders

http://ng.neurology.org//cgi/collection/developmental_disorders

Information about reproducing this article in parts (figures,tables) or in its entirety can be found online at:

http://ng.neurology.org/misc/about.xhtml\#permissions

Information about ordering reprints can be found online: http://ng.neurology.org/misc/addir.xhtml\#reprintsus

Neurol Genet is an official journal of the American Academy of Neurology. Published since April 2015, it is an open-access, online-only, continuous publication journal. Copyright Copyright $\odot 2021$ The Author(s). Published by Wolters Kluwer Health, Inc. on behalf of the American Academy of Neurology.. All rights reserved. Online ISSN: 2376-7839.

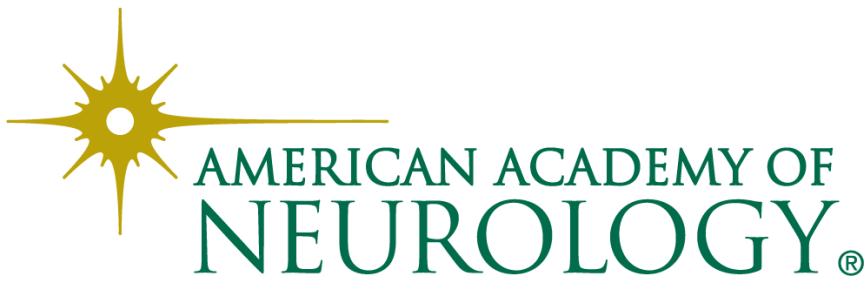

